\section{The brain is the conductor: diet- induced inflammation overlapping physiological control of body mass and metabolism}

\author{
O cérebro é o maestro: inflamação induzida por dieta interfere no \\ controle fisiológico da adiposidade corporal e do metabolismo
}

Licio Augusto Velloso'

\begin{abstract}
Obesity is currently a worldwide pandemic. It affects more than 300 million humans and it will probably increase over the next 20 years. The consumption of calorie-rich foods is responsible for most of the obesity cases, but not all humans exposed to high-calorie diets develop the disease. This fact has prompted researchers to investigate the mechanisms linking the consumption of high-calorie diets to the generation of an imbalance between energy intake and expenditure. According to recent studies, the exposure to fat-rich diets induces an inflammatory response in the hypothalamic areas involved in the control of feeding and thermogenesis. The inflammatory process damages the neuronal circuitries that maintain the homeostatic control of the body's energy stores, therefore favoring body mass gain. This review will focus on the main advances obtained in this field. Arq Bras Endocrinol Metab. 2009;53(2):151-158.
\end{abstract}

Keywords

Inflammation; hypothalamus; metabolism; weight control; fat-rich diet

\section{RESUMO}

Obesidade é hoje um grave problema de saúde pública no mundo. Mais de 300 milhões de pessoas são obesas e esse número deve crescer substancialmente nos próximos 20 anos. As dietas ricas em calorias são a principal causa de obesidade, porém, nem todos os indivíduos expostos a dietas altamente calóricas se tornam obesos. Tal fato estimulou pesquisadores a investigarem os mecanismos que ligam o consumo de dietas ricas em calorias ao desenvolvimento de um balanço inadequado entre consumo e gasto energético. De acordo com estudos recentes, o consumo de dietas ricas em gorduras induz a ativação de uma resposta inflamatória nas áreas do hipotálamo envolvidas com o controle da fome e da termogênese. Tal processo inflamatório lesa os circuitos neuronais que mantêm o controle homeostático das reservas corporais de energia, favorecendo assim o ganho de massa adiposa. Esta revisão irá focar os principais avanços obtidos nesta área. Arq Bras Endocrinol Metab. 2009;53(2):151-158.

Descritores

Inflamação; hipotálamo; metabolismo; controle de peso; dieta rica em gordura
1 Laboratório de Sinalização Celular Faculdade de Ciências Médicas da Universidade Estadual de Campinas (FCM-Unicamp), Campinas, SP, Brasil
Correspondence to:

Licio Augusto Velloso

Laboratório de Sinalização Celular da FCM-Unicamp

13084-970 - Campinas, SP, Brasil avelloso@fcm.unicamp.br.

Received in Feb/18/2009 Accepted in Feb/20/2009

\section{INTRODUCTION}

$\mathrm{O}$ besity has become one of the most important health problems in the world. It affects more than 300 million people and impinges more than $20 \%$ of people living in selected regions, such as the United States, Russia, Australia, England and the Czech Republic. In Brazil, the current prevalence of obesity is about $10 \%$ and, as projected by the World Health Organization (WHO), it may reach $25 \%$ of the population by the year 2025 (1).

Except for some rare types of monogenic defects (2), obesity occurs due to the complex combination of multiple environmental and genetic factors (3). The consumption of highly energetic and palatable foods is 
among the most important epidemiological predisposing factors to this disease (3). However, not all people exposed to this type of diet develop obesity, and this fact has long intrigued researchers. As currently known, the main reason for the protective phenotype is the intrinsic capacity to maintain the homeostatic control of energy stores in the body (3). Specialized neurons of the hypothalamus play a central role, connecting the information provided by leptin and insulin, regarding the size of fat depots, with the mechanisms that regulate hunger and thermogenesis (4). As long as the system is perfectly coupled, changes in energy intake are matched by proportional modifications in energy expenditure. Thus, it is clear that, in order to understand the mechanisms behind the majority of obesity cases, the phenomena that connect the consumption of highly energetic foods with the loss of energy homeostasis must be deciphered.

A series of recent studies has provided a solid basis to the hypothesis that in diet-induced obesity, the hypothalamus is targeted by an inflammatory process that leads to a defective regulation of energy homeostasis (5-8). In the present review, to discuss this complex mechanism, we will be presenting the physiological role of the hypothalamus in the control of food intake and energy expenditure. Next, a discussion on how nutrients can disrupt the correct functioning of this highly specialized organ will be brought up. Finally, it the mechanisms involved in diet-induced hypothalamic resistance to adipostatic signals will be presented.

\section{THE PHYSIOLOGICAL CONTROL OF FOOD INTAKE AND THERMOGENESIS}

Two distinct neuron subpopulations of the arcuate nucleus of the hypothalamus act as the sensors for the energy stores in the body and coordinate a complex network of neurons that, in due course, control the balance of hunger versus satiety, and pro- versus anti-thermogenesis $(9,10)$. These first-order neurons are equipped with receptors and intracellular molecular systems capable of detecting subtle or chronic changes in the levels of hormones and nutrients present in the bloodstream (10). The response to these changes is based on the modulation of the firing rate and of neurotransmitter production and release by specific neuron bodies (11).

The subpopulations of neurons of the arcuate nucleus are characterized by the neurotransmitters each one produces. One of the subpopulations expresses the orexygenic peptides, NPY and AgRP, while the other expresses the anorexygenic POMC $(\alpha-\mathrm{MSH})$ and CART $(10,11)$ (Figure 1). Both subpopulations project to the lateral $(\mathrm{LH})$ and paraventricular $(\mathrm{PVN})$ nuclei of the hypothalamus, where they control the functions of second-order neurons. In the PVN, two distinct subpopulations of neurons produce the anorexigenic and pro-thermogenic neurotransmitters, TRH and CRH (12), while in the LH, two other subpopulations produce the predominantly orexygenic neurotransmitter orexin and the predominantly anti-thermogenic $\mathrm{MCH}$ (12) (Figure 1). During fasting or when body energy stores are depleted, the expressions of NPY and AgRP are induced, while POMC and CART are inhibited. This coordinated response is dependent on the simultaneous sensing of decreased nutrient availability, reduced levels of the adipostatic hormones leptin and insulin, reduced levels of the gut hormones CCK, GLP-1 and GIP and increased levels of the gastric hormone ghrelin (13). Active NPY/AgRPergic neurons send inhibitory projections to the $\mathrm{PVN}$, reducing the expressions of TRH and CRH, and stimulatory projections to the $\mathrm{LH}$, boosting the activities of the orexin and $\mathrm{MCH}$ expressing neurons. Conversely, following a meal or when body energy stores are replenished, NPY/AgRPergic neurons are inhibited and POMC/CARTergic neurons are active. In this context, nutrient availability and the levels of leptin and insulin are increased, as well as the levels of CCK, GLP-1 and GIP. In opposition, the level of ghrelin is reduced. The result is the inhibition of orexin and $\mathrm{MCH}$ neurons in the $\mathrm{LH}$ and the activation of the CRH and TRH neurons in the PVN (11-13).
A

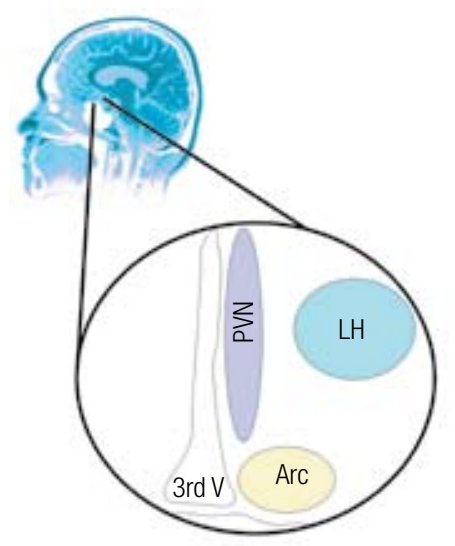

B

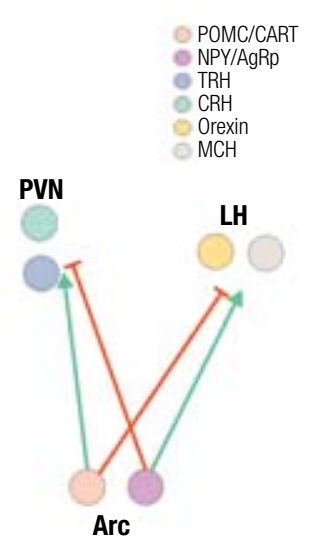

Figure 1. Specialized hypothalamic neurons localized in the arcuate (Arc), paraventricular (PVN) and lateral (LH) nuclei control food intake and thermogenesis (A). In each nuclei, at least two distinct subpopulations of neurons exert specific functions (B). 
The mechanisms by which second-order neurons effectively control food intake and energy expenditure are under intense investigation. $\mathrm{MCH}$ neurons play an important role in the control of energy expenditure $(12,14)$. Increased expression of this neurotransmitter restrains animal motility and reduces the expression of the mitochondrial uncoupling protein, UCPl, in brown adipose tissue, together leading to a reduction in energy output $(12,14)$. Conversely, the knockout of $\mathrm{MCH}$ produces a lean phenotype due to a combined effect on feeding and thermogenesis $(15,16)$, while the knockout of the main $\mathrm{MCH}$ receptor, MCHRl, produces a lean phenotype, predominantly due to increased energy expenditure (17). Orexin has a predominant role in arousal and the control of feeding $(18,19)$. Injection of this neurotransmitter in the hypothalamus generates a potent orexigenic stimulus; however, little is known about the mechanisms behind this response (19). In opposition to the neurotransmitters of the $\mathrm{LH}$, the PVN neurotransmitters, TRH and $\mathrm{CRH}$, have rather overlapping roles in the control of hunger and thermogenesis $(20,21)$. TRH biosynthesis and release is controlled by multiple inputs coming from POMC neurons, leptin direct signals, and from other sources such as T3 (22). Although most studies explore the role of TRH upon the control of thyroid function and, consequently, on thermogenesis, there are plenty of data showing its direct action in the control of feeding (23). Similarly to TRH, CRH production is modulated by a number of different inputs, such as signals emanating from the arcuate nucleus and direct actions of leptin, GLP-1 and histamine $(24,25)$. The reduction of appetite is the most studied effect of $\mathrm{CRH}$, but several studies point to its pro-thermogenic effects as well (26). Nevertheless, little is known about the mechanisms controlling these phenomena. Some additional pathways of the central nervous system play modulatory roles in energy balance. The connections of first- and second-order neurons of the hypothalamus with these systems are only beginning to be deciphered (11). The actions of serotonin and norepinephrine to induce satiety and increase energy expenditure have been known for a long time $(27,28)$. Even so, these neurotransmitters play rather unspecific and minor regulatory roles in this context, as evidenced by the moderate/severe adverse effects produced by drugs acting through the control of these neurotransmitters and by the limited efficiency of all treatment regimens employing such drugs (29).
Recently, a new player came onto the scene. The development of drugs that interact with the receptor for the endogenous cannabinoid system revealed an additional mechanism for the control of food intake and thermogenesis. The first clues about the orexygenic properties of endogenous cannabinoid system came from the observation that the consumption of exogenous cannabinoids present in marijuana produces a powerful sensation of hunger (30). The characterization of the main endocannabinoid receptor, $\mathrm{CBl}$, and the development of synthetic antagonists for this receptor created hope for the production of new, safer and more effective drugs for the treatment of obesity (30). However, clinical data show that the weight loss produced by this class of drug is only marginally superior to that produced by inhibitors of serotonine re-uptake and adverse affects, such as depression and increased rate of suicide, have precluded the widespread use of these compounds for the treatment of obesity (31).

Although, as discussed above, a number of mechanisms play a role in the control of hypothalamic neurons involved in the regulation of energy homeostasis, leptin and insulin are regarded as the most robust peripheral signal providers to the hypothalamus (10). Leptin is produced predominantly by the adipose tissue in direct proportion to body fat mass (32), and though some peripheral actions have been attributed to this hormone, such as the regulation of insulin production by pancreatic $\beta$-cells (33), modulation of insulin action (34), and control of a number of immune functions $(35,36)$, the basomedial hypothalamus, particularly the arcuate nucleus, is the main site of its action $(10,32)$.

Both NPY/AgRPergic and POMC/CARTergic neurons express high levels of the main form of the leptin receptor, the $\operatorname{ObRb}(10,32)$ (Figure 2). This is a monomeric transmembrane protein that belongs to the type I cytokine receptor family $(32,37)$. Like the other members of this family, the ObRb lacks intrinsic enzymatic activity and depends on at least one associated kinase, JAK2, to transduce its signal (37). Upon leptin binding to the ObRb, a dimmerization of receptor units accompanies JAK2 autophosphorylation and the tyrosine phosphorylation of two residues (Tyr985 and Tyr1138) in the receptor itself (37). These events generate the possibility of activation of at least three distinct intracellular signaling pathways (37). Tyrosine phosphorylation of Tyr985 recruits the tyrosine phosphatase SHP2, which mediates the activation of the p2lras/ ERK signaling pathway $(32,37)$. Tyrosine phosphory- 

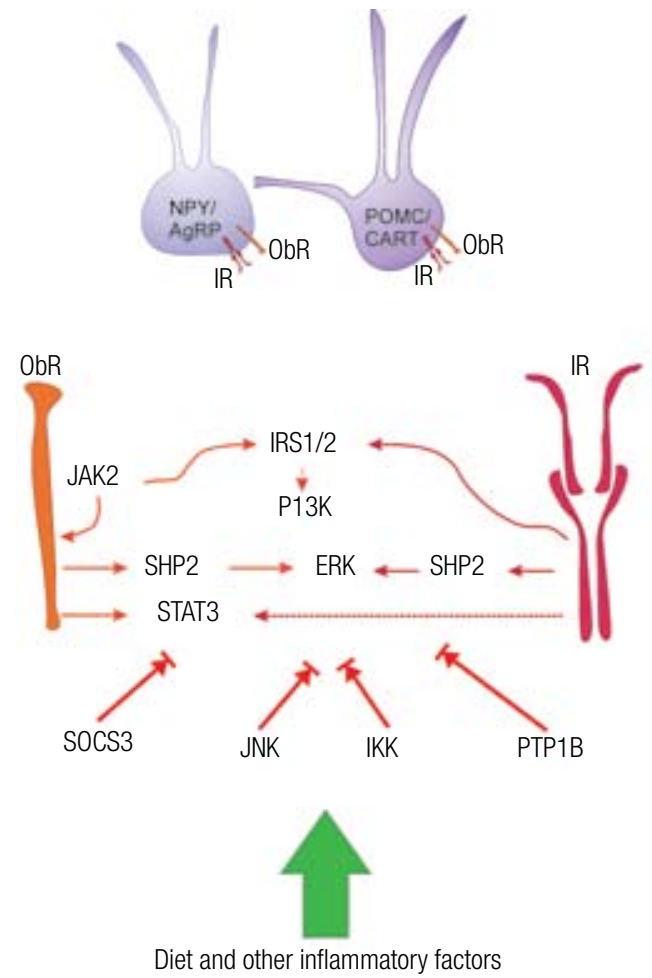

Figure 2. Leptin and insulin are the main adipostatic hormones signaling to the hypothalamus. The main signal transducing pathways and inhibitor mechanisms induced by diet and other inflammatory factors are depicted.

lation of Tyrl 138 recruits STAT3 to the ObRb, leading to STAT3 tyrosine phosphorylation and translocation to the nucleus, providing a fast-track for leptin-induced control of gene expression (32). Finally, the autophosphorylation of JAK2 leads to the recruitment and tyrosine phosphorylation of adaptor proteins IRSI/2, which promotes the activation of PI3-kinase and its downstream signaling (32). It is possible that several other signaling pathways are also activated through the ObRb. These may include other substrates for JAK2, since a large number of Tyr residues may be phosphorylated following kinase activation, and the engagement of as yet unknown tyrosine kinases, since signal transduction through IRS1/PI3-kinase/Akt can occur even in the absence of the activation of JAK2 (35).

Each of the signaling pathways controlled by leptin plays a role in a specific compartment of the complex response to this hormone. In POMC/CARTergic neurons, the activation of JAK2/STAT3 signaling by leptin leads to increased transcriptional activity, boosting the expression of POMC $(10,12)$. This effect is enhanced by simultaneous insulin action, but apparently not reproduced by insulin alone (38). Conversely, the activation of PI3 kinase activity seems to play a minor role in the control of neurotransmitter expression, but it is essential for neurotransmitter release in the synaptic terminals. This effect is achieved through the control of neuronal firing rate. Once activated by either leptin or insulin, PI3 kinase mediates neuronal depolarization by inhibiting ATP-sensitive potassium channels $(11,39)$. The central role for PI3 kinase in this context is further evidenced by the fact that genetic or pharmacological modulations of phosphatases that control the signaling through PI3 kinase, such as PTEN and 5'-ptase IV, have profound effects on feeding behavior $(40,41)$.

Since not only POMC/CARTergic neurons, but also the orexigenic NPY/AgRPergic neurons harbor the leptin receptor, an important question was raised regarding the mechanisms by which leptin can simultaneously activate the anorexygenic neurons, while inhibiting the orexigenic neurons. The answer to this question came from the demonstration that POMC/CARTergic neurons project inhibitory fibers to NPY/AgRPergic neurons. When leptin levels are high, the activation of POMC/CARTergic neurons leads to a simultaneous inhibition of NPY/AgRPergic neurons, a phenomenon that superimposes the direct signals that are eventually generated through the ObRb, as well as the insulin receptor present in these orexigenic neurons (11).

Finally, it is important to mention that, besides its predominant actions in the arcuate nucleus, a number of studies have shown that leptin can act through cells present in other regions of the brain. Some of these cells may act only to modulate the main signals delivered by arcuate nucleus neurons, but in some cases, specific responses may control other physiological phenomena primarily controlled by leptin (42).

Insulin is the second most important adipostatic signal provider to the hypothalamus. Studies from the late 1960's pioneered the investigation concerning the roles of insulin in the central nervous system (43). However, only after the identification of leptin in 1994 were the functions of insulin in the hypothalamus described $(38,44)$. In the arcuate nucleus, both NPY/ AgRPergic and POMC/CARTergic neurons express receptors for insulin $(4,10)$. As in peripheral tissues, in the hypothalamus, insulin activates signal transduction through IRS1 and IRS2, leading to the engagement of the PI3K/Akt/Foxol pathway $(10,38,45)$. In addition, insulin induces a potent cross-talk with the leptin signaling pathway through the activation of JAK2 (38). In fact, one of the most important functions of insulin in the hypothalamus is to enhance leptin's signal $(10,38)$. In the absence of the insulin signal in the hy- 
pothalamus, much of the adipostatic function of leptin is lost, as demonstrated using neuron-specific insulin receptor knockout mice (46).

Therefore, under physiological conditions the hypothalamus, acting under the control of peripheral factors, coordinates perfect coupling between food intake and energy expenditure. As long as the system is fully active, body mass is maintained steady.

\section{INDUCTION HYPOTHALAMIC DYSFUNCTION BY NUTRIENTS}

Excessive caloric intake, despite the type of nutrient consumed, is a primary risk factor for the development of obesity (47). However, a number of epidemiological studies have shown that populations consuming preferentially diets rich in fat are especially prone to gain body mass $(48,49)$. In addition to its caloric value, fatty acids are known to exert functional modulation of several tissues and cell types. Therefore, we tested the hypothesis that high fat consumption could modulate gene expression in the hypothalamus. Using a macroarray approach, the expressions of more than 1,000 hypothlamic genes were simultaneously evaluated. More than $15 \%$ of the analyzed genes were somehow modulated by the diet. Clustering the genes by function revealed that immune response related to genes were the most affected $(5,50)$. Among the fatty acids commonly present in the occidental diet, the long-chain saturated ones are the most harmful. By activating signal transduction through receptors of the toll-like receptor family, especially the TLR4, these fatty acids activate an inflammatory response by the microglia cells in the hypothalamus (6). Signaling through JNK and NFKB leads to the induction of cytokine gene transcription and local levels of TNF- $\alpha$, IL- $1 \beta$, IL- 6 and IFN- $\gamma$ raise and nourish hypothalamic inflammation (6).

Following fatty acid-induced activation of TLR4 signaling, cells turn on an adaptive mechanism that has the biological purpose of adapting protein synthesis to the harms imposed by the inflammation. This mechanism is called endoplasmic reticulum stress and, depending on the magnitude and duration of the harm, can enhance inflammatory signal or induce apoptosis (51).

The ER is the organelle responsible for the synthesis and processing of membrane and secretory proteins (52). When the ER homeostasis is disrupted, the accumulation of misfolded and unfolded proteins in the ER lumen ensues $(52,53)$. To deal with this condition, the affected cells activate a complex signaling system known as the unfolded protein response (UPR), aimed at preserving cell integrity, while the harmful condition persists $(52,53)$. One of the outcomes of the activation of UPR is the induction of the expression of cytokines and proteins involved in immune surveillance $(54,55)$.

If the exposure to saturated fatty acids is prolonged and, depending on some as yet unknown genetic determinants, a pro-apototic response is induced, leading to the preferential loss of anorexigenic neurons in the arcuate nucleus (Moraes and Velloso, unpublished results). As time passes, a gradual modification in the relative numbers of orexygenic and anorexygenic neurons takes place and a novel set point for body adiposity is generated. This fact may explain why some obese patients are so resistant to different behavioral and pharmacological approaches employed to treat obesity. Thus, activation of TLR4 signal transduction, followed by the induction of hypothalamic ER-stress, is the main mechanisms linking the high consumption of dietary fats to the induction of hypothalamic dysfunction in obesity.

\section{MECHANISMS INVOLVED IN DIET-INDUCED HYPOTHALAMIC RESISTANCE TO ADIPOSTATIC SIGNALS}

As long as a perfect coupling between caloric intake and energy expenditure is preserved, body adiposity is maintained at a physiological level (47). One of the mechanisms involved in the breakdown of this equilibrium is the installation of resistance to the anorexigenic and thermogenic effects of leptin and insulin (5). In animal models, the resistance to both hormones can be quantified by a simple method. In intracerebroventricular cannulated lean rodents, the acute injection of leptin leads to a reduction of up to $60 \%$ of spontaneous food intake over 12 hours (38). Injecting insulin rather then leptin produces a reduction of up to $50 \%$ in food intake. However, if the same tests are performed in obese animals, the effects of both hormones are blunted by at least $50 \%$. To identify the molecular mechanism responsible for producing the functional resistance to leptin and insulin, several groups have evaluated different models of obesity and the most remarkable findings reveal that, upon diet-induced obesity, the induction of inflammatory activity, specifically in the hypothalamus, leads to the activation of intracellular signaling pathways that promote a negative cross-talk with the leptin and insulin signaling systems, which impairs their physiological anorexygenic activities $(38,45)$. 
Currently, four distinct mechanisms are known to play a role in diet- and cytokine-induced resistance to leptin and/or insulin in the hypothalamus of rodents. Both TNF- $\alpha$ and the consumption of fat-rich diets can induce the activation of the serine-kinase JNK in hypothalamic cells. Activated JNK targets IRS1, catalyzing its serine phosphorylation and hampering its capacity to act appropriately as a docking protein for PI3-kinase. This results in reduced insulin-induced activation of Akt coincides with functional resistance to insulin. Inhibition of JNK by a specific chemical inhibitor or inhibition of TNF- $\alpha$ by a blocking monoclonal antibody reverses the effects of the diet or the cytokine and reestablishes a normal tonus for insulin activity in the hypothalamus (5).

IKK, the serine kinase involved in IkB phosphorylation/degradation, which leads to NFKB activation, is another mediator involved in diet-induced insulin resistance in the hypothalamus (7). In rats fed on a diet rich in fat, activated IKK promotes the serine phosphorylation of IRS1, hampering the signal transduction of insulin. Whilst in peripheral organs of insulin resistant animals, the inhibition of IKK by salicylates was proven to reinstall correct insulin activity (56), no data regarding the pharmacological inhibition of this enzyme in the hypothalamus is available so far, but it is expected to work in a similar manner.

SOCS3 belongs to a family of inducible proteins that respond to stimulus by a number of cytokines, hormones and growth factors. Once expressed, SOCS proteins provide a negative feedback to the original signal, acting as a regulatory loop to restrain over stimulation. In diet-induced obesity, the expression of SOCS3 is significantly stimulated in the hypothalamus, providing a negative control for leptin and insulin signaling $(57,58)$. At least two mechanisms are involved in SOCS3 inhibition of leptin and insulin signaling. The first one depends on the physical interaction of SOCS3 with either the ObRb or STAT3 (32). Under these circumstances, the transduction of the signal is inhibited because the sites for interaction between proteins are blocked by SOCS3. The second mechanism depends on SOCS3-dependent ubiquitination of IRS proteins. Following ubiquitin tagging, IRS proteins are directed to proteosomic degradation, restraining signal transduction through this pathway (32). The important role for SOCS3 in diet-induced obesity is further confirmed by the fact that genetic abrogation of SOCS3 is capable of protecting mice from diet-induced obesity (32).
An additional mechanism involved in diet- and cytokine-induced resistance to anorexigenic signaling in the hypothalamus is the induction of expression of the tyrosine phosphatase PTPIB. Once induced, this enzyme catalyses the dephosphorylation of the IR and IRS proteins, turning off the signals generated by insulin. The knockout of the PTP1B gene or the knockdown of PTP1B by antisense oligonucleotides protects experimental animals from diet- and cytokine-induced insulin resistance in the hypothalamus (59).

\section{CONCLUDING REMARKS}

Following the identification of leptin, 15 years ago, great advance has been obtained in the understanding of physiological mechanisms of body mass control. It has allowed a substantial advance in the characterization of the mechanisms involved in the development of obesity. It is currently believed that, in most of the obesity cases, the hypothalamus is the primarily affected organ. Upon high consumption of dietary fat, a local inflammatory process is triggered by the activation of TLR4 signaling. Neurons and microglia are affected and ER-stress is induced. Depending on genetic background, specific subpopulations of neurons are lost by apoptosis, thus enhancing the harmful effects of inflammation. With time, the homeostatic control of body energy stores is lost and obesity emerges. Future studies will focus on the characterization of similar phenomena in human beings and on the evaluation of specific antiinflammatory approaches to treat obesity.

Acknowledgements: Studies performed at the Laboratory of Cell Signaling were supported by grants from Fundação de Amparo à Pesquisa do Estado de São Paulo (Fapesp), Conselho Nacional de Desenvolvimento Científico e Tecnológico (CNPq). The Laboratory of Cell Signaling is a member of the National Institute of Obesity and Diabetes (INCT de obesidade e diabetes - CNPq/MCT). The author thanks to Doctor N. Conran for editing the English grammar.

Disclosure: No potential conflict of interest relevant to this article was reported.

\section{REFERENCES}

1. Kopelman PG. Obesity as a medical problem. Nature. 2000;404(6778):635-43.

2. Farooqi S, O'Rahilly S. Genetics of obesity in humans. Endocr Rev. 2006;27(7):710-8.

3. Galgani J, Ravussin E. Energy metabolism, fuel selection and body weight regulation. Int J Obes (Lond). 2008;32 Suppl 7:S109-19.

4. Velloso LA, Araujo EP, de Souza CT. Diet-induced inflammation of the hypothalamus in obesity. Neuroimmunomodulation. 2008;15(3):189-93. 
5. De Souza CT, Araujo EP, Bordin S, Ashimine R, Zollner RL, Boschero $\mathrm{AC}$, et al. Consumption of a fat-rich diet activates a proinflammatory response and induces insulin resistance in the hypothalamus. Endocrinology. 2005;146(10):4192-9.

6. Milanski M, Degasperi G, Coope A, Morari J, Denis R, Cintra DE, et al. Saturated fatty acids produce an inflammatory response predominantly through the activation of TLR4 signaling in hypothalamus: implications for the pathogenesis of obesity. J Neurosci. 2009;29(2):359-70.

7. Zhang X, Zhang G, Zhang H, Karin M, Bai H, Cai D. Hypothalamic IKKbeta/NF-kappaB and ER stress link overnutrition to energy imbalance and obesity. Cell. 2008;135(1):61-73.

8. Yang L, Hotamisligil GS. Stressing the brain, fattening the body. Cell. 2008;135(1):20-22

9. Flier JS, Maratos-Flier E. Obesity and the hypothalamus: novel peptides for new pathways. Cell. 1998;92(4):437-40.

10. Schwartz MW, Woods SC, Porte D, Jr., Seeley RJ, Baskin DG. Central nervous system control of food intake. Nature. 2000;404:661-71.

11. Horvath TL. The hardship of obesity: a soft-wired hypothalamus. Nat Neurosci. 2005;8(5):561-5.

12. Cone RD. Anatomy and regulation of the central melanocortin system. Nat Neurosci. 2005;8(5):571-8.

13. Badman MK, Flier JS. The gut and energy balance: visceral allies in the obesity wars. Science. 2005;307(5717):1909-14.

14. Pereira-da-Silva M, Torsoni MA, Nourani HV, Augusto VD, Souza $\mathrm{CT}$, Gasparetti AL, et al. Hypothalamic melanin-concentrating hormone is induced by cold exposure and participates in the control of energy expenditure in rats. Endocrinology. 2003;144(11):4831-40.

15. Qu D, Ludwig DS, Gammeltoft S, Piper M, Pelleymounter MA, Cullen MJ, et al. A role for melanin-concentrating hormone in the central regulation of feeding behaviour. Nature. 1996;380(6571):243-7.

16. Shimada M, Tritos NA, Lowell BB, Flier JS, Maratos-Flier E. Mice lacking melanin-concentrating hormone are hypophagic and lean. Nature. 1998;396(6712):670-4.

17. Marsh DJ, Weingarth DT, Novi DE, Chen HY, Trumbauer ME, Chen AS, et al. Melanin-concentrating hormone 1 receptor-deficient mice are lean, hyperactive, and hyperphagic and have altered metabolism. Proc Natl Acad Sci U S A. 2002;99(5):3240-5.

18. Chemelli RM, Willie JT, Sinton CM, Elmquist JK, Scammell T, Lee $C$, et al. Narcolepsy in orexin knockout mice: molecular genetics of sleep regulation. Cell. 1999;98(4):437-51.

19. Farr SA, Banks WA, Kumar VB, Morley JE. Orexin-A-induced feeding is dependent on nitric oxide. Peptides. 2005;26(5):759-5.

20. Appel NM, Owens MJ, Culp S, Zaczek R, Contrera JF, Bissette G, et al. Role for brain corticotropin-releasing factor in the weightreducing effects of chronic fenfluramine treatment in rats. Endocrinology. 1991;128(6):3237-46.

21. Schuhler S, Warner A, Finney N, Bennett GW, Ebling FJ, Brameld JM. Thyrotrophin-releasing hormone decreases feeding and increases body temperature, activity and oxygen consumption in Siberian hamsters. J Neuroendocrinol. 2007;19(4):239-49.

22. Fekete C, Lechan RM. Negative feedback regulation of hypophysiotropic thyrotropin-releasing hormone (TRH) synthesizing neurons: role of neuronal afferents and type 2 deiodinase. Front Neuroendocrinol. 2007;28(2-3):97-114.

23. Valassi E, Scacchi M, Cavagnini F. Neuroendocrine control of food intake. Nutr Metab Cardiovasc Dis. 2008;18(2):158-68.

24. Nicholson RC, King BR, Smith R. Complex regulatory interactions control CRH gene expression. Front Biosci. 2004;9:32-9.

25. Sarkar S, Fekete C, Legradi G, Lechan RM. Glucagon like peptide-1 (7-36) amide (GLP-1) nerve terminals densely innervate corticotropin-releasing hormone neurons in the hypothalamic paraventricular nucleus. Brain Res. 2003;985(2):163-8.
26. Solinas G, Summermatter S, Mainieri D, Gubler M, Montani JP, Seydoux J, et al. Corticotropin-releasing hormone directly stimulates thermogenesis in skeletal muscle possibly through substrate cycling between de novo lipogenesis and lipid oxidation. Endocrinology. 2006;147(1):31-8.

27. Waldbillig RJ, Bartness TJ, Stanley BG. Increased food intake, body weight, and adiposity in rats after regional neurochemical depletion of serotonin. J Comp Physiol Psychol. 1981;95(3):391-405.

28. Leibowitz SF, Miller NE. Unexpected adrenergic effects of chlorpromazine: eating elicited by injection into rat hypothalamus. Science. 1969;165(893):609-11.

29. Mancini MC, Halpern A. Pharmacological treatment of obesity. Arq Bras Endocrinol Metabol. 2006;50(2):377-89.

30. Di Marzo V, Matias I. Endocannabinoid control of food intake and energy balance. Nat Neurosci. 2005;8(5):585-9.

31. Vinod $K Y$, Hungund $B L$. Role of the endocannabinoid system in depression and suicide. Trends Pharmacol Sci. 2006;27(10):539-45.

32. Myers MG, Cowley MA, Munzberg H. Mechanisms of leptin action and leptin resistance. Annu Rev Physiol. 2008;70:537-56.

33. Seufert J, Kieffer TJ, Habener JF. Leptin inhibits insulin gene transcription and reverses hyperinsulinemia in leptin-deficient ob/ob mice. Proc Natl Acad Sci U S A. 1999;96(2):674-9.

34. Barzilai N, Wang J, Massilon D, Vuguin P, Hawkins M, Rossetti L. Leptin selectively decreases visceral adiposity and enhances insulin action. J Clin Invest. 1997;100(12):3105-10.

35. Mansour E, Pereira FG, Araujo EP, Amaral ME, Morari J, Ferraroni NR, Ferreira DS, et al. Leptin inhibits apoptosis in thymus through a janus kinase-2-independent, insulin receptor substrate-1/ phosphatidylinositol-3 kinase-dependent pathway. Endocrinology. 2006;147(11):5470-9.

36. Matarese G, La Cava A. The intricate interface between immune system and metabolism. Trends Immunol. 2004;25(4):193-200.

37. Munzberg $\mathrm{H}$, Myers MG, Jr. Molecular and anatomical determinants of central leptin resistance. Nat Neurosci. 2005;8(5):566-70.

38. Carvalheira JB, Siloto RM, Ignacchitti I, Brenelli SL, Carvalho CR, Leite $A$, et al. Insulin modulates leptin-induced STAT3 activation in rat hypothalamus. FEBS Lett. 2001;500(3):119-24.

39. Niswender KD, Baskin DG, Schwartz MW. Insulin and its evolving partnership with leptin in the hypothalamic control of energy homeostasis. Trends Endocrinol Metab. 2004;15(8):362-9.

40. Plum L, Ma X, Hampel B, Balthasar N, Coppari R, Munzberg H, et al. Enhanced PIP3 signaling in POMC neurons causes KATP channel activation and leads to diet-sensitive obesity. J Clin Invest. 2006;116(7):1886-901.

41. Bertelli DF, Araujo EP, Cesquini M, Stoppa GR, Gasparotto-Contessotto M, Toyama MH, et al. Phosphoinositide-specific inositol polyphosphate 5-phosphatase IV inhibits inositide trisphosphate accumulation in hypothalamus and regulates food intake and body weight. Endocrinology. 2006;147(11):5385-99.

42. Hayes MR, Skibicka KP, Bence KK, Grill HJ. Dorsal hindbrain AMP-Kinase as an intracellular mediator of energy balance. Endocrinology. 2008. [Epub ahead of print]

43. Margolis RU, Altszuler N. Insulin in the cerebrospinal fluid. Nature. 1967;215(5108):1375-6.

44. Air EL, Benoit SC, Clegg DJ, Seeley RJ, Woods SC. Insulin and leptin combined additively to reduce food intake and body weight in rats. Endocrinology. 2002;143(6):2449-52.

45. Torsoni MA, Carvalheira JB, Pereira-Da-Silva M, de CarvalhoFilho MA, Saad MJ, Velloso LA. Molecular and functional resistance to insulin in hypothalamus of rats exposed to cold. Am J Physiol Endocrinol Metab. 2003;285(1):E216-23.

46. Bruning JC, Gautam D, Burks DJ, Gillette J, Schubert M, Orban $\mathrm{PC}$, et al. Role of brain insulin receptor in control of body weight and reproduction. Science. 2000;289(5487):2122-5. 
47. Cohen DA. Obesity and the built environment: changes in environmental cues cause energy imbalances. Int J Obes (Lond). 2008;32 Suppl 7:S137-142.

48. Ogden CL, Yanovski SZ, Carroll MD, Flegal KM. The epidemiology of obesity. Gastroenterology. 2007;132(6):2087-102.

49. Damiao R, CastroTG, Cardoso MA, Gimeno SG, Ferreira SR. Dietary intakes associated with metabolic syndrome in a cohort of Japanese ancestry. Br J Nutr. 2006;96(3):532-8.

50. De Souza CT, Pereira-da-Silva M, Araujo EP, Morari J, AlvarezRojas F, Bordin S, et al. Distinct subsets of hypothalamic genes are modulated by two different thermogenesis-inducing stimuli. Obesity (Silver Spring). 2008;16(6):1239-47.

51. Zhang K, Kaufman RJ. From endoplasmic-reticulum stress to the inflammatory response. Nature. 2008;454(7203):455-62.

52. Xu C, Bailly-Maitre B, Reed JC. Endoplasmic reticulum stress: cell life and death decisions. J Clin Invest. 2005;115(10):2656-64.

53. Schroder M, Kaufman RJ. ER stress and the unfolded protein response. Mutat Res. 2005;569(1-2):29-63.

54. Krappmann D, Wegener E, SunamiY, Esen M, Thiel A, Mordmuller $\mathrm{B}$, et al. The IkappaB kinase complex and NF-kappaB act as master regulators of lipopolysaccharide-induced gene expression and control subordinate activation of AP-1. Mol Cell Biol. 2004;24(14):6488-500.

55. Marciniak SJ, Ron D. Endoplasmic reticulum stress signaling in disease. Physiol Rev. 2006;86(4):1133-49.

56. Prattali RR, Barreiro GC, Caliseo CT, Fugiwara FY, Ueno M, Prada $\mathrm{PO}$, et al. Aspirin inhibits serine phosphorylation of insulin receptor substrate 1 in growth hormone treated animals. FEBS Lett. 2005;579(14):3152-8.

57. Bjorbaek C, Elmquist JK, Frantz JD, Shoelson SE, Flier JS. Identification of SOCS-3 as a potential mediator of central leptin resistance. Mol Cell. 1998;1(4):619-25.

58. Munzberg H, Flier JS, Bjorbaek C. Region-specific leptin resistance within the hypothalamus of diet-induced obese mice. Endocrinology. 2004;145(11):4880-9.

59. Picardi PK, Calegari VC, Prada Pde O, Moraes JC, Araujo E, Marcondes MC, et al. Reduction of hypothalamic protein tyrosine phosphatase improves insulin and leptin resistance in diet-induced obese rats. Endocrinology. 2008;149(8):3870-80. 